\title{
The determinants of Polish movies' box office performance in Poland
}

\author{
Natalia Gmerek* \\ University of Warsaw, Poland \\ E-mail:ngmerek@wz.uw.edu.pl
}

Received: 02.02.2015 / Revised: 07.04.2015 / Accepted: 14.04.2015 / Published online: 24.04.2015

\begin{abstract}
This paper provides an empirical analysis of financial performance of movies produced in Poland between 2000 and 2011. To understand the reason for a motion picture's success in the theatrical channel various factors concerning total domestic box office performance were regressed from the box office results of 207 movies. This study proposes that the success of a movie can be determined by three elements: product attributes, distribution-related variables and information sources.

The results show that the production budget, movie type - sequel or adaptation, star power, genre, scope of the movie's release and audience rating are closely related to box office, influencing it in a positive way. On the other hand, critics' rating, release date (April, July, August) and strong competitive pressure from other movies have a substantial negative influence on box office. The results suggest that the overall movie quality (product-related variables) has an economically and statistically significant effect on total demand for Polish movies.
\end{abstract}

JEL classification: M300, M310, M390, M00

Keywords: motion picture success, box office performance, multiple regression analysis

\section{INTRODUCTION}

For almost a century, and especially since World War II, Hollywood has dominated the national and international motion picture markets (Scott, 2004). Despite early beliefs that this domination could be redressed, the European and Hollywood film industries constantly battle. In spite of the strong domestic performance of Indian, Nigerian and, to a lesser degree, Korean productions, American film still dominates the global box office. While the number of films produced in India, Nigeria and Europe respectively is greater than in the US, the number of films produced does not correlate with the level of international exposure or revenue earned (Kerrigan, 2010). Global recognition and acceptance of American English and cultural references give American films an automatic advantage over European films on the movie market. It has become so difficult for European films, particularly non-English language productions, to penetrate international markets

*niversity of Warsaw, 1/3 Szturmowa Street, 02-678 Warsaw, Poland. 
that European producers concentrate on their national audiences trying to fulfill their preferences as precisely as they can.

In this case, the key marketing challenge is to identify factors responsible for adequately high box office. Despite the growing number of publications on the factors determining motion picture performance, no explicit position concerning the relevancy and direction of influence of individual factors has been developed. The uniqueness of the motion picture markets in individual countries requires an individualized approach, consisting in the selection and operationalization of the analyzed factors. Based on a review of marketing literature, we can conclude that most of the research conducted so far in this respect focuses mainly on the American market, although in the last few years there has been a noticeable development of research dedicated to the identification of determinants of motion picture performance on individual European and Asian markets.

At the moment, the theatrical movie market in Poland is undergoing a phase of intense development. Every year more and more domestic cinematic productions are completed; however, the knowledge on the factors of a box office success or failure of a movie product is still rather scarce.

This paper seeks to fill this gap by presenting empirical results regarding the yet unexplored European market. The study concerns in particular the influence of a broad range of product attributes, distribution variables and information sources on the financial performance of feature films produced in Poland.

\section{LITERATURE REVIEW}

\subsection{The notion of a motion picture's success - an overview of measures and indicators}

Numerous measures and indicators have been developed in marketing literature and market practice. These include (Simonton, 2009, pp. 403-405; Hadida, 2009, pp. 301-304):

- $\quad$ total domestic box office

- $\quad$ first-week box office

- $\quad$ length of run

- distributors' rentals

- $\quad$ exhibitors' rentals

- $\quad$ return on investment $-\mathrm{ROI}$

The most popular measure applied by scientists who conducted research on the market success of motion pictures is the total box office (Hirschman and Pieros, 1985; Litman and Kohl, 1989; Wyatt and Badgar, 1990; Prag and Casavant, 1994; Sawhney and Eliashberg, 1996; De Vany and Walls, 1996; Eliashberg and Shugan, 1997; Ravid, 1999; De Vany and Walls, 1999; Ginsburg and Weyers, 1999; Bagella and Becchetti, 1999; Lampel and Shamsie, 2000; Zufryden, 2000; Eliashberg, Jonker, Sawhney and Wierenga, 2000; De Vany and Lee, 2001; Nelson, Donihue, Waldman and Wheaton, 2001; Hand, 2001; Canterbery and Marvasti, 2001; Collins, Hand and Snell, 2002; Elberse and Eliashberg, 2003; Holbrook, 2005; Delmestri, Montanari and Usai, 2005; Reinstein and Snyder, 2005; Ainslie, Dreye and Zufryden, 2005; Chang and Ki, 2005; Desai and Basuroy, 2005; De Vany and Walls, 2002; Walls, 1997, 2005a, 2005b; Liu, 2006; Lee, 2006; Hennig-Thurau, Houston and Sridhar, 2006; Sood, Dreze, 2006; Hadida, 2009; Simonton, 2009). There are several premises for the popularity of this measure among the researchers and analysts dealing with motion picture marketing. These include: regularity and rapidity of the collection of data on the number of tickets sold by specialized trade institutions, accessibility of data (total box office numbers are officially published), the possibility of comparison and analysis of performance-related data in various aspects (i.a. time and geographical location). Due to the 
specific character of a motion picture's length of run, namely the importance of the first screening phase, which is in most cases decisive in respect of the final movie performance results in the cinematic channel, the researchers more and more often focus on the first-week box office as an indicator of box office performance of a motion picture (De Vany and Walls, 1996; De Vany and Walls, 1999; Reinstein and Snyder, 2005); Ainslie, Dreye and Zufryden, 2005; Chang and Ki, 2005; Basuroy, Desai and Talukdar, 2006; Liu, 2006; Hennig-Thurau, Houston and Sridhar, 2006; Hennig-Thurau, Houston and Walsh, 2007).

Another measure of the market success of a motion picture is the length of run, that is the number of weeks of theatrical screenings. This criterion does not enjoy particular popularity among scientists and is not subject to deeper analyses. Marketing research proves that extension of a movie's availability in theatres does not result in better box office performance (Sochay, 1994; De Vany and Walls, 1996; 1997; Walls, 1998; Jedidi, Krider and Weinberg, 1998); Lampel and Shamsie, 2000; Nelson, Donihue, Waldman and Wheaton, 2001; Chang and Ki, 2005; Lee, 2006). There are situations when a certain movie, after several screening weeks, generates higher sales than a movie screened for several dozen weeks.

Two further measures refer to the income from sales received by intermediaries on the movie market: distributor and exhibitor (Faulkner and Anderson, 1987; Baker and Faulkner, 1991; Sochay, 1994; Baimbridge, 1997; Albert, 1999; Litman, 1983; Smith and Smith, 1986; Wallace, Siegerman, and Holbrook, 1993; De Vany and Walls, 2002). For services provided to a given movie producer, these entities charge fees constituting part of the income from the tickets sold. This measure is highly subjective because the amount of fees received by individual entities is a derivative of both their negotiation force and market position.

The last and rarest measure encountered in professional and scientific publications is "return on investment", that is a profitability indicator applied in order to measure the effectiveness of a company's operation (Ravid, 1999; Lehmann, Weinberg, 2000; Miller and Shamsie, 2001; De Vany and Walls, 1999, 2002; Ravid and Basuroy, 2004; Jansen, 2005). The ROI depends on individual profit and the box office result per unit of invested assets. Due to the information necessary for the construction of this measure, the ROI is applied relatively rarely. The greatest problem for researchers is the determination of operational profit on the basis of data concerning the amount of total costs related to a movie production, in particular the P\&A costs, which are difficult to assess. The method is considered useless and not accurate enough in the case of the motion picture market.

The analysis of determinants of motion picture performance conducted in this article refers to the total box office - a measure commonly assumed by the professional and scientific environment both on the foreign and Polish markets.

\subsection{The determinants of motion picture performance - classification and importance on the market}

The literature describing factors which influence the motion picture performance written so far focuses on two trends: psychological approach and economic approach. The psychological approach focuses on the problems related to the behavior of motion picture viewers. The marketing research conducted in this area mostly concerns questionnaire research sounding the opinions of individual viewers. It explains the motives and factors influencing consumers in the decision-making process regarding the selection of the movie theatre from among various forms of mass entertainment, as well as the selection of a particular movie ${ }^{1}$.

\footnotetext{
The psychological approach is presented in detail in the following publications: Cuadrado, M. and Frasquet, M. (1999), 'Segmentation of cinema audiences: an exploratory study applied to young consumers', Journal of Cultural Economics, Vol. 23 No. 4, pp. 257-267; D'Astous, A. and Touil, N. (1999), 'Consumer evaluations of movies on the basis of critics' judgments', Psychology \& Marketing, Vol. 16 No. 8, pp. 677-686;
} 
The economic approach is focused on the issues of the quest for determinants influencing the financial performance of a given movie production. For this purpose, researchers usually use data concerning the sales of individual movie productions which are gathered in specialist databases. The analyses of dependencies between movie performance (box office) and selected factors are conducted with the use of various statistical tools.

In this article the author takes into consideration only the economic approach.

Based on broad literature (especially the work of Chang and Ki, 2005), this study proposes that the success of a movie is determined by three essential elements: product attributes, distributionrelated variables and information sources.

Product attributes are brought in and assembled by the producers and the artistic and technical teams during a film's production process. They include creative factors such as production costs, screenplay, genre and reputation of the film's main contributors - the director and leading actors. The most important factor is the production budget, or what is often referred to as the "negative cost". If we take into consideration the impact of the budget size on the movie's success, we are able to discern two possible effects. Firstly, potential consumers see a movie's budget as an indicator of quality as large budgets translate into lavish sets and costumes, expensive digital processing, and special effects that lead to an increased attractiveness for the audiences (Basuroy et al., 2003; Litman, 1982; Litman and Kohl, 1998). This indicator function is likely to prove true in cost-intensive genres, notably action and science-fiction movies (Hennig-Thurau et al., 2001). Secondly, production costs are an indication of the economic potential of a movie and the producer's expectations that the movie's story, cast and crew are attractive enough to generate the necessary earnings and assure an appropriate yield (Hennig-Thurau et al., 2001).

The production budget is largely devoted to the realization of a script. Therefore, many researchers have examined the characteristics of the screenplay which contribute to cinematic success. The resulting investigations tended to focus on sequels or movies based on a familiar story or another culture-inherent element (Hennig-Thurau et al., 2009; Sood and Dreze, 2006; Dhar et al., 2012). Taking into consideration the financial performance, sequels make good economic sense: the probability of making money is higher in the case of a sequel, especially in the early weeks of the theatrical run (De Vany and Walls, 1999; Ravid, 1999). Several researchers (Prag and Casavant, 1994; Ravid, 1999) proved that whether or not a film was a sequel turned out to be important in predicting the financial success of the movie. In the case of films based on adaptations it turns out that they tend to receive higher critical praise and succeed in the award categories, but do not stand out at the box office, and may actually perform worse if the adaptation is based on a play (Simonton, 2005b).

Vast film literature indicates that genre is an important influencer of audience expectations since people are more likely to pay attention to something that is personally relevant to them because they attach certain entertainment value to it (Hixson, 2006). Some movie genres have been analyzed concerning predictions of box office performance. For example, the comedy genre was a major topic in several studies (Litman, 1982; Sochay, 1994). In addition, the popularity of sci-fi/fantasy and horror genres was empirically supported in other literature (Litman, 1982).

Ultimately, the quality of a cinematic product must depend on the artists and experts who cooperate in its production. The empirical literature concentrates almost exclusively on whether movie stars ensure success, taking into consideration the criterion of financial performance (Basuroy et al., 2003; De Vany and Walls, 1999; Holbrook, 1999; Litman, 1983; Litman and Kohl, 1998; Prag and Casavant, 1994; Ravid, 1999; Sochay, 1994; Wallace et al., 1993; Simonton,

Moul, Ch. C. (2006), 'The day after tomorrow: longer issues in theatrical exhibition', Marketing Science, Vol. 25 No. 6, pp. 665-666; Moon, S., Bergey, P.K and Iacobucci, D. (2010), 'Dynamic effects among movie ratings, movie revenues, and viewer satisfaction', Journal of Marketing, Vol. 74 No. 1, pp. 108-121. 
2009). In the research works the concept of "star" is defined in many different ways and therefore the results are not consistent. Some studies indicate that the presence of stars has a positive impact on box office success (Hadida, 2009; Sochay, 1994; Wallace et al., 1993), other studies claim that stars have no effect on box office performance (De Vany and Walls, 1999; Litman, 1983; Litman and Kohl, 1998; Prag and Casavant, 1994; Elberse, 2005, Ravid, 1999). Another problem lies in wages and fees of actors featuring in a movie. The wages of actors who are liked by viewers and able to attract them to movie theatres account for a considerable share of the production budget. Wages of actors appearing in "Lethal Weapon 4" totaled USD 50 million, half of which was earned by Mel Gibson (Hennig-Thurau et al., 2001, p. 10). This indicates a two-directional impact of "movie stars" on a motion picture's financial success: on the one hand, they could have a potential positive impact on ticket sales and on the other hand, high costs of wages generate a negative effect on the profitability of a production for its producer and other investors (HennigThurau, Houston and Walsh, 2007, pp.84-85).

Sedgwick and Pokorny (1999) emphasize that wages of actors sometimes absorb such a large part of the production budget that extra sales revenues do not cover that additional expenditure. A common phenomenon is that the most famous actors do not earn enough to cover their costs (Sedgwick and Pokorny, 1999, pp. 319-323).

The director is usually considered as the most important person during the shooting of a motion picture. For the audience, the director's performance is much more difficult to evaluate than that of actors because the director's work is "invisible" to them. However, there are certain well-known directors and viewers have higher expectations of films connected with these names. Still, most of the previous studies (Litman, 1982; Litman and Kohl, 1998; Sochay, 1994) reported that the effect of the director's name was rather insignificant.

In France, Italy and Germany, strong box office records of directors positively influence their latest film's admissions (Bagella and Becchetti 1999; Delmestri et al., 2005). These results confirm the leading role of movie directors in the European cinema (Svejenova, 2005).

Distribution-related variables consist of a film's release strategy, in particular its release date, number of prints and market power of the distributor. One of the main strategic decisions made by distributors is the one regarding a movie's release date. The two important considerations factored into this decision are the strong seasonal effect in the demand for movies and the competition that will be encountered throughout the movie's run (Einav, 2002). When analyzing the American market, the period when movies generate the largest box office revenues are summer months (Wyatt and Badgar, 1990; Wallace et al., 1993; Sochay, 1994; Chang and Ki, 2005; Krider and Weinberg, 1998). The second important period is Christmas, and the third one is Easter (Litman, 1983; Sochay, 1994; Chang and Ki, 2005). The largest falls in the sales of theatre tickets are noted in the first months of each year (Simonton, 2009). The importance of the release date is greatly magnified by the fact that the performance during the first week accounts for a sizeable amount of the overall performance of the movie. On average, box office revenues in the first week account for almost forty percent of the movie's total domestic revenues (Einav, 2002). Typically, movies with higher expected revenues are released on higher demand weekends.

A film that might otherwise do very well in the box office may find itself pushed aside by an abundance of competing films that opened at the same weekend or shortly before. Relevant literature indicates that there are two studies discussing empirical verifications of the competition on the theatrical movies' market. The first one by Ainslie et al. (2005) refers to the American market, the second one by Basuroy et al. (2005) refers to the British market. The researchers unanimously state that simultaneous premieres of movies dedicated to the same audience or representing the same genre translate into worse sales results both in the first week and throughout the whole run. 
Another crucial decision made by the distributors is the one concerning the scope of a movie's release, that is the number of prints. There are three main types of release: wide release, platform release and limited release. Wide releases, which are most common in the case of main distributors, are those in which the movie screening begins in a large number of theatres, typically several thousand, accompanied by a very extensive national advertising campaign. Platform releases involve an initial release in a smaller number of theatres, often restricted to large cities, with advertising concentrated rather in local newspapers. In subsequent weeks the movie expands to additional screens and to more rural areas. Limited releases are those in which the movie is released in two or three cities without strong expectations of the movie's potential for a wider release (Einav, 2002).

Wide-release films often tend to earn most at the first weekend of release (De Vany and Walls, 1999), and are also prone to generate larger box office revenues by the end of their theatrical run (Litman and Kohl, 1998; Sochay, 1994; Simonton, 2005b; Zufryden, 1996; Zuckerman and Kim, 2003; Elberse and Eliashberg, 2003; Ainslie et al., 2005; Hennig-Thurau et al. 2006).

The market power of the distributor has not been subject to a lot of research yet. In this paper it is assumed that distributors with high market power will gain a competitive advantage over other competitors in terms of securing and continuing a larger number of screens, forcing theatre owners to conduct more marketing activities in relation to their movies. For instance, Chang and $\mathrm{Ki}(2005)$ found that the length of the film run mostly depends on the distributor: films released by major distributors were screened in theatres longer.

Information sources mostly come into play around the film's first release and fall into three categories: customer-based (audience rating), expert-based (critics' rating) and advertising expenditures. The motion picture industry is an "experiential" product market, characterized by product quality information asymmetry between companies and consumer (Eliashberg and Sawhney, 1994). Advertisement is the main source of information for the audience on the upcoming movie; therefore, it plays a crucial role concerning the box office success of theatrical movies. Elliot and Simmons (2008) suggest that an important role of film advertising is to transmit quality signals to potential audiences. Advertising activities conducted to promote a movie product should be oriented towards the achievement of the highest box office numbers, in particular in the first period of the film's run (Basuroy et al., 2006; Zufryden, 1996).

Several studies have established a link between advertising expenditures and box-office grosses. Prag and Casavant (1994), Zufryden (1996; 2000), and Moul (2004) all found evidence for a positive relationship between advertising and weekly or cumulative revenues. Lehmann and Weinberg (2000) showed that the level of advertising for a movie is positively correlated with opening strength. Elberse and Eliashberg (2003) found that the positive relationship between advertising expenditures and opening-week revenues is largely due to a second positive correlation, namely that between advertising expenditures and the screens allocated to a movie in its opening week.

There is also a clear hierarchy in advertising channels, with viewers considering television as more useful than printed media and radio. Consumers do not perceive trailers as advertising but rather as an opportunity to gain initial consumption experiences, thus it is extremely important for a film trailer to reach as wide an audience as possible (Hixson, 2006). Lastly, movie web page requests account for $14 \%$ of the variance of a film's box office revenues, and, similarly to theatrical attendance, they peak in their first week (Zufryden, 2000).

In the motion picture industry critics play a significant role as far as the consumers' decision is concerned. Most researchers have identified a positive relation between the critics' judgment and box office success (Sawhney and Eliashberg, 1996; Sochay, 1994; Lampel and Shamsie, 2000; Collins et al., 2002; Zuckerman and Kim, 2003; Basuroy et al., 2003; Chang and Ki, 2005; Desai and Basuroy, 2005; Holbrook, 2005; Hennig-Thurau et al., 2006; Hennig-Thurau et al., 
2007). Nonetheless, some investigators have found no relationship between these two factors (Delmestri et al., 2005; Reinstein and Snyder, 2005), whereas others have found a negative association between them (Simonton, 2005a). These contradictory results reflect to a great extent the complexity of the phenomenon. The precise relation between the verdicts of the critics and box office returns varies across the successive weeks of the film's theatrical run (Basuroy et al, 2003; Eliashberg and Shugan, 1997) and depends on whether the reviews are positive or negative in valence (Basuroy et al., 2003). Kamakura et al. (2006) imply that the correlation of aggregate critic opinion and movie appeal will in general be stronger than the correlation of an individual critic's opinion and movie appeal since aggregate critic opinion represents the consensus among the majority of experts.

One of the most understudied variables in movie success research is the audience rating. It reflects the degree of preference of moviegoers and may function as an influencer which produces a word-of-mouth effect. Word of mouth has a stronger impact on the moviegoers' willingness to watch a particular film than advertising (Moul, 2007). Similarly, word of mouth defined as audience ratings on popular movie websites such as the Internet Movie Database (IMDb) and Yahoo!Movies positively impacts the duration of a film's theatrical run and its total box office revenues, particularly in the first (Chang and $\mathrm{Ki}, 2005$ ) and five to six first weeks after release (Liu, 2006). The volume, not the valence (actual value), of user ratings posted on Yahoo!Movies correlates positively with daily box office revenues in the first two weeks of a film's run (Duan et al., 2005) as well as with the weekly and total box office revenues (Liu, 2006).

\section{METHODOLOGY AND DATA}

\subsection{Formulating the regression model}

A sales regression analysis was conducted in order to identify factors determining the sale of movie tickets. On developed motion picture markets the sales regression analysis constitutes a frequently applied tool serving the purpose of identification of factors determining motion picture performance. It started to be popular in the $80 \mathrm{~s}$ of the previous century, with the publication of the article written by Litman (1983) entitled Predicting success of theatrical movies: an empirical study. In that article, the regression model for motion pictures screened in the United States was presented for the first time. In our times, more and more researchers acknowledge this method as the most adequate and useful one in the analysis of dependencies on the movie market, allowing for the verification whether there is a correlation between variables, facilitating the assessment of strength and direction of this correlation and enabling the formulation of a mathematical form reflecting these correlations (Litman, 1983; Litman and Kohl, 1989; Sochay, 1994; Prag and Casavant, 1994; Smith and Smith, 1986; Ravid, 1999; Simonoff and Sparrow, 2000).

\subsection{Presentation and operationalization of variables in the model}

The available research results estimate multiple regression functions that examine the success drivers of Polish feature films in terms of total box office. Independent variables of the model consist of a vector of attributes that are supposed to affect a film's performance. Three categories of independent variables were employed in the analysis: product attributes (production budget, genre, type of screenplay, number of famous actors, popularity of the director), distributionrelated variables (market power of the distributor, release date and competition intensity, type of release) and information sources (advertising expenditures, critics' rating and audience rating). An additional variable referring to the movie's length of run was taken into consideration in the model, namely the first-week box office. 
The operationalization of variables and sources of data which constituted the basis for the preparation of individual variables taken into consideration in the model are described in detail in Table 1:

Table 1

Operationalization of model variables

\begin{tabular}{|c|c|c|c|}
\hline \multicolumn{2}{|c|}{ Variable } & \multirow{2}{*}{$\begin{array}{c}\text { Description of measure } \\
\text { Total box office in the cinematic channel }\end{array}$} & \multirow{2}{*}{$\begin{array}{l}\text { Data source } \\
\text { boxoffice.pl website }\end{array}$} \\
\hline Movie success & Box office Poland & & \\
\hline \multirow[t]{5}{*}{ Product attributes } & Production budget & $\begin{array}{l}\text { Costs of production activities, except for } \\
\text { the P\&A costs }\end{array}$ & Polish Film Institute \\
\hline & Genre & $\begin{array}{l}\text { Classification which takes into account } \\
\text { six genres, that is: comedy, drama, social } \\
\text { drama, action movie, historical movie, } \\
\text { family movie, thriller }\end{array}$ & www.filmpolski.pl website \\
\hline & Type of screenplay & $\begin{array}{l}\text { Division into two groups: continuation/ } \\
\text { adaptation of various works of art or } \\
\text { original screenplay }\end{array}$ & www.filmpolski.pl website \\
\hline & $\begin{array}{l}\text { Number of famous } \\
\text { actors }\end{array}$ & $\begin{array}{l}\text { In order to properly classify an actor to } \\
\text { one of the two groups: popular actor / } \\
\text { less popular actor, the so-called "Google } \\
\text { browser statistics" was used }\end{array}$ & www.filmpolski.pl website \\
\hline & $\begin{array}{l}\text { Popularity of the } \\
\text { director }\end{array}$ & $\begin{array}{l}\text { In order to properly classify the director } \\
\text { to one of the two groups: popular director/ } \\
\text { less popular director, the so-called } \\
\text { "Google browser statistics" was used }\end{array}$ & www.filmpolski.pl website \\
\hline \multirow[t]{5}{*}{$\begin{array}{l}\text { Distribution-related } \\
\text { variables }\end{array}$} & $\begin{array}{l}\text { Market power } \\
\text { of the distributor }\end{array}$ & $\begin{array}{l}\text { Value market share of a given distributor } \\
\text { on a movie market }\end{array}$ & boxoffice.pl website \\
\hline & Release date & The month of the cinematic premiere & boxoffice.pl website \\
\hline & $\begin{array}{l}\text { International } \\
\text { competition }\end{array}$ & $\begin{array}{l}\text { Differentiation between two competitive } \\
\text { situations in the first week: strong } \\
\text { foreign competition or weak } \backslash \text { no foreign } \\
\text { competition }\end{array}$ & boxoffice.pl website \\
\hline & $\begin{array}{l}\text { National } \\
\text { competition }\end{array}$ & $\begin{array}{l}\text { Differentiation between two competitive } \\
\text { situations in the first week: strong } \\
\text { national competition or weak } \backslash \text { no national } \\
\text { competition }\end{array}$ & \\
\hline & Type of release & Number of prints & boxoffice.pl website \\
\hline \multirow[t]{3}{*}{ Information sources } & $\begin{array}{l}\text { Advertising } \\
\text { expenditures }\end{array}$ & Costs of advertising activities & $\begin{array}{l}\text { AdExpert advertising } \\
\text { expenditures listing }\end{array}$ \\
\hline & Critics' rating & $\begin{array}{l}\text { Division of films into two groups: films } \\
\text { which had negative reviews }(*, * *, * * *) \\
\text { and films which had positive reviews } \\
(* * * *, * * * * *, * * * * * *)\end{array}$ & $\begin{array}{l}\text { the daily newspaper } \\
\text { Gazeta Wyborcza }\end{array}$ \\
\hline & Audience rating & $\begin{array}{l}\text { Division of films into two groups: films } \\
\text { which had negative reviews (marked } 1^{*}- \\
\left.5^{*}\right) \text { and films which had positive reviews } \\
\left(\text { marked } 6^{*}-10^{*}\right) \text {. }\end{array}$ & www.filmweb.pl website \\
\hline $\begin{array}{l}\text { Product life cycle- } \\
\text { related variable }\end{array}$ & $\begin{array}{l}\text { Interest of viewers } \\
\text { in the first week }\end{array}$ & First-week box office & boxoffice.pl website \\
\hline
\end{tabular}

Source: own study. 
The data concerning movie attendance were obtained from the boxoffice.pl website. The information necessary for the operationalization of the model variables was drawn from several different data sources, including the boxoffice.pl website, the www.filmweb.pl website, the daily newspaper Gazeta Wyborcza, AdExpert advertising expenditures listing and the Polish Film Institute.

\subsection{Characteristics of research sample}

The analyzed sample consists of 207 motion pictures produced and released in Poland between 2000 and 2011 for which complete data on the variables were available. The applied selection of the research sample is described as non-random research sample. It is to a large extent an exhaustive research, taking into consideration the analyzed period of time, because almost all components are subject to measurement. The main aim was to analyze as many theatrical movies which were available in terms of necessary research information as possible.

Among all 207 analyzed films the most numerous group consisted of comedies (88 movies, that is $42.51 \%$ ). The second group are dramas (78 movies, that is $37.68 \%$ ), the third group consisted of action movies ( 12 movies, that is $5.80 \%$ ). The remaining genres have a small share in the analyzed group of motion pictures: social dramas ( 8 movies, that is $3.86 \%$ ), historical movies ( 7 movies, that is $3.38 \%$ ), family movies ( 7 movies, that is $3.38 \%$ ), thrillers (6 movies, that is $2.90 \%$ ), fantasy movies ( 1 movies, that is $0.49 \%$ ). A significant majority of movies (170 movies, that is $82.13 \%$ ) is based on an original screenplay. 29 movies (that is $14 \%$ ) are adaptations of other works of art, and 8 movies (that is 3.87\%) are a cinematic continuation. An average production budget of a Polish motion picture amounts to PLN 3,318,595. On average 2 popular actors play in a Polish motion picture, 50 movies (that is $24.15 \%$ ) have a known and popular director, and 157 movies (that is $75.85 \%$ ) have a less popular director.

The distribution of 72 motion pictures $(34.78 \%)$ was conducted by entities with a significant position on the movie market: 3 movies - UIP, 6 movies - Forum Film, 35 movies - ITI Cinema, 19 movies - Monolith and Monolith Plus, 9 movies - Gutek Film. The distribution of 135 movies $(65.22 \%)$ was conducted by small national business entities with a scarce movie distribution market share in Poland. Most movies had their premieres in November (28 movies), September (27 movies) and October (26 movies). Other months characterized by the highest number of theatrical premieres are: February (23 movies), March (22 movies), April (21 movies), May (15 movies), January (12 movies), August (11 movies), June (9 movies), December (8 movies) and July (5 movies).

In the case of 114 motion pictures $(55.07 \%)$ there was a strong competition of foreign productions, and in the case of 93 movies $(44.93 \%)$ weak competition of foreign productions. In the case of 54 motion pictures $(26.09 \%$ ) there was a strong competition of Polish productions, in the case of 117 movies (56.52\%) there was a weak competition of Polish productions, 36 motion pictures $(17.39 \%)$ did not have any competition from Polish productions. An average number of prints for screenings in cinemas amounts to 51 .

An average level of budget for advertisement in the case of Polish motion pictures amounts to PLN 292,327.

The critics assessed movie productions as follows: 125 movies $(60.39 \%)$ received a negative review whereas 82 movies (39.61\%) had positive reviews. The structure of motion pictures according to the viewers' assessment is as follows: 161 movies $(77.78 \%)$ had a negative review whereas 46 movies $(22,22 \%)$ had positive reviews. 


\section{RESULTS}

The starting point in the process of the establishment of the regression function for a motion picture's performance was the correlation matrix. The values of all correlation coefficients set for individual pairs of variables differed from zero, which indicated a connection between the analyzed variables. This fact allowed for the application of a sequence method to the selection of independent variables for the model, that is for the establishment of a model with all potential independent variables as well as their gradual elimination until a satisfactory version of the model was formulated. Unimportant variables have been removed from the model (on the basis of the values of coefficients of statistical significance) so as to ensure possibly high adjustment of theoretical values to empirical values.

Table 2 represents the final stepwise results with total domestic box office as the dependent variable.

Table 2

Multiple regression function results (domestic total box office)

\begin{tabular}{|c|c|c|c|c|}
\hline Variable & Coefficient & Std. Error & t-Statistic & Prob. \\
\hline Production budget & 0.134760 & 0.008371 & 4.152553 & 0.0001 \\
\hline Sequel/Adaptation & 342.2337 & 134.4275 & 2.545861 & 0.0123 \\
\hline Genre (comedy) & 247.0735 & 126.9384 & 1.783932 & 0.0023 \\
\hline Genre (history) & 473.3136 & 365.6991 & 2.037312 & 0.0038 \\
\hline Leading actors' star power & 53.23059 & 22.06010 & 2.412980 & 0.0174 \\
\hline Number of prints & 5.746202 & 0.947121 & 6.067021 & 0.0000 \\
\hline Release (April) & -194.4947 & 105.8095 & -1.838160 & 0.0087 \\
\hline Release (July) & -195.8765 & 86.43279 & -2.539678 & 0.0065 \\
\hline Release (August) & -196.1011 & 72.22829 & -2.715017 & 0.0077 \\
\hline International competition & -254.1699 & 89.16561 & -2.850538 & 0.0052 \\
\hline National competition & -138.1409 & 59.78027 & -2.350487 & 0.0047 \\
\hline Positive critics' rating & -53.90901 & 24.76479 & -2.795410 & 0.0061 \\
\hline Positive audience ratings & 243.9834 & 98.30537 & 2.367096 & 0.0196 \\
\hline First-week box office & 14.86262 & 35.93837 & 2.392822 & 0.0023 \\
\hline $\mathrm{C}$ & -142.2826 & 129.6138 & -4.183833 & 0.0001 \\
\hline R-squared & 0.938616 & \multicolumn{2}{|c|}{ Mean dependent var } & 88.76711 \\
\hline Adjusted R-squared & 0.925688 & \multicolumn{2}{|c|}{ S.D. dependent var } & 1025.551 \\
\hline S.E. of regression & 30.26745 & \multicolumn{2}{|c|}{ Akaike info criterion } & 14.72333 \\
\hline Sum squared resid & 14643545 & \multicolumn{2}{|c|}{ Schwarz criterion } & 15.03847 \\
\hline Log likelihood & -913.5696 & \multicolumn{2}{|c|}{ F-statistics } & 68.73338 \\
\hline Durbin-Watson stat & 1.861107 & \multicolumn{2}{|c|}{ Prob (F-statistic) } & 0.000000 \\
\hline
\end{tabular}

Source: the results of the author's own analysis.

This table reports the coefficients and $\mathrm{t}$-statistics with significance oscillating at the $5 \%$ level. 
The variables taken into account in the final version of the model, thus determining the total box office (TBO), are: production budget (PB), screenplay as a continuation or adaptation of another work of art (SA), comedy genre $(\mathrm{GC})$, historical genre $(\mathrm{GH})$, number of popular actors playing in the movie (PA), number of prints (NP), opening night in April (AP), opening night in June (JU), opening night in August (AU), strong international competition (SIC), strong national competition (SNC), positive critics' reviews (PCR), positive audience reviews (PAR) and firstweek box office (FBO).

The application of linear interdependencies allowed for a quite thorough reproduction of the variability of the total box office of a motion picture.

On the basis of the estimation table presented above we can express the analytical form of the model describing total box office of a motion picture as follows:

$$
\begin{gathered}
\mathrm{DTBO}=0.1348 * \mathrm{~PB}+342.2337 * \mathrm{SA}+247.0735 * \mathrm{GC}+473.3136 * \mathrm{GH}+53.2306 * \mathrm{PA} \\
+5.7462 * \mathrm{NP}-194.4947 * \mathrm{AP}-195.8765 * \mathrm{JU}-196.1011 * \mathrm{AU}-254.1699 * \mathrm{SIC} \\
-138.1409 * \mathrm{SNC}-53.9091 * \mathrm{PCR}+243.9834 * \mathrm{PAR}+14.86262 * \mathrm{FBO}-142.2826
\end{gathered}
$$

The interpretation of parameters of the above model is as follows ${ }^{2}$ :

0.1348*PB - it means that if the production budget increases by one unit (that is by PLN 1,000), then the total box office increases by $\mathbf{1 3 4 . 8}$ viewers (assuming that the remaining independent variables remain stable).

342.2337*SA - it means that if the screenplay is a continuation/adaptation of another work of art, then the total box office increases by $\mathbf{3 4 2 , 2 3 3 . 7}$ viewers (assuming that the remaining independent variables remain stable).

473.3136* $\mathbf{G H}$ - it means that if the movie is a historical movie, then the total box office increases by $473,313.6$ viewers (assuming that the remaining independent variables remain stable).

247.0735*GC - it means that if the movie is a comedy, then the total box office increases by 247,073.5 viewers (assuming that the remaining independent variables remain stable).

53.2306*PA - it means that if the number of popular actors in the movie increases by 1 person, then the total box office increases by 53,230.6 viewers (assuming that the remaining independent variables remain stable).

$5.7462 * \mathbf{N P}$ - it means that if the total number of prints increases by one unit (that is by 1 print), then the total box office increases by $\mathbf{5 , 7 4 6 . 2}$ viewers (assuming that the remaining independent variables remain stable).

$-194.4947 * \mathrm{M} 4$ - it means that if the movie has its premiere in April, then the total box office decreases by 194,494.7 viewers (assuming that the remaining independent variables remain stable).

$-195.8765 * \mathrm{M} 7$ - it means that if the movie has its premiere in July, then the total box office decreases by $\mathbf{1 9 5 , 8 7 5 . 5}$ viewers (assuming that the remaining independent variables remain stable).

$-196.1011 *$ M8 - it means that if the movie has its premiere in August, then the total box office decreases by 196,101.1 viewers (assuming that the remaining independent variables remain stable).

-254.1699*IC - it means that if the movie has its premiere at the time when a competitive foreign movie which achieved high box office performance is screened, then the total box office decreases by $\mathbf{2 5 4 , 1 6 9 . 9}$ viewers (assuming that the remaining independent variables remain stable).

The dependent variable Y, that is total box office, is expressed in thousands of people, which influences the interpretation of the model's parameters. 
$-138.1409 * \mathrm{NC}$ - it means that if the movie has its premiere at the time when a competitive Polish movie which achieved high box office performance is screened, then the total box office decreases by 138,140.9 viewers (assuming that the remaining independent variables remain stable).

$-53.9091 * P C R$ - it means that if the critics' reviews were positive, the total box office decreases by 53,909.1 viewers (assuming that the remaining independent variables remain stable).

243.9834*PAR - it means that if the viewers' opinions are positive, the total box office increases by $\mathbf{2 4 3 , 9 8 3 . 4}$ viewers (assuming that the remaining independent variables remain stable).

$14.86262 *$ FBO - it means that if the first-week box office increases by one unit (that is 1,000 viewers), then the total box office increases by 14,862 viewers (assuming that the remaining independent variables remain stable).

$\mathbf{- 1 4 2 . 2 8 2 6}$ - constant $C$, without interpretation.

The assessment of statistical significance of the model was based on the assessment of stochastic parameters, verifying if the model is adjusted to empirical data (adjusted coefficient of determination, standard deviation of the residual component), and the assessment of structural parameters aimed at verification whether all parameters connected with independent variables were statistically significantly different from zero - this can be assumed from low values of empirical significance levels. The total statistical significance of the parameters in the model has been confirmed by means of the Fisher test.

The model explains to a great extent the variances concerning the total number of viewers (adjusted $\mathrm{R}^{2}=0.926$ ). It means that the established model explains the variability of the total box office of a motion picture in Poland at $92.6 \%$. Therefore, we can state that the variability of total box office was described quite precisely by the abovementioned factors.

Standard deviation of the residual component $($ S.E. of regression $=30.26745)$ means that average deviation of theoretical total box office from the empirical total box office amounts to $+/-30,267$ viewers. It is caused by the influence of factors which were not taken into account in the model.

In the abovementioned model all parameters connected with independent variables are statistically significantly different from zero - this can be assumed from low values of empirical significance levels (Probability).

The total statistical significance of parameters in the model was confirmed by means of the Fischer test, for which the empirical significance level amounts to 0.000 .

Due to the fact that the model was established for large-scale data, i.e. refers to 207 cinematic productions, there is no need to analyze the auto-correlation of the residual component.

The model that includes total box office as a dependent variable shows that the production budget, movie type - sequel or adaptation, number of famous actors, genre - comedy and history, number of prints, positive audience rating were significantly related to box office influencing it in a positive way. On the other hand, favorable critics' rating, movies released in April, July, August and strong competitive pressure from other movies were significantly related to box office results in a negative way. The results suggest that the overall movie quality (product-related variables) has an economically and statistically significant effect on the movie's total demand. 


\section{DISCUSSION}

The sales regression analysis designed on the basis of the number of viewers of Polish motion pictures allowed the identification of factors that have a significant, both positive and negative, influence over the movie theatre attendance and factors that are insignificant for a box office success on the theatrical movie market in Poland.

Marketing implications concerned with implementation of the developed regression model on the Polish theatrical movie market mean identification of activities and steps to be taken in the movie production organization process to efficiently manage theatrical movie sales.

\section{Product activities}

At the pre-production stage it is important to develop a good script being the basis of a future movie.

In Poland, similarly to the United States of America, theatrical movies being a continuation of a well-known cinematic theme or an adaptation of an existing work of art enjoy greater popularity among the audience than movies based on an original script. That is why it is worth to give a thought to the selection of a movie subject that is to a certain extent known to the audience from various works of art and entertainment contexts. In the case of movie producers who are planning to stay in the movie business on a long-term basis, the production of film series that continue the previous threads of movies and the experiences of characters already known to viewers can be taken into consideration. Another solution are movie adaptations of popular books, theatrical plays, TV series, computer games etc., that is of products of the cultural goods and services market which have already been recognized by wide audience.

The primary factor that translates into the final box office performance is the movie genre. The research also shows that historical movies and comedies achieve best box office performance. In the Polish cinema the historical aspect is rather rare and unexploited. It is also a less popular genre, nonetheless with a great potential concerning the number of viewers. Film producers should take into consideration the plot threads which are worth fictionalization and allow for the creation of an interesting story able to catch the attention of modern cinemaniacs.

Comedy is the most frequent genre on the Polish movie market, enjoying vast popularity among viewers. The last decade witnessed mostly romantic comedies which attract mostly female audience. Nevertheless, there is a visible return to thriller-comedies that enjoyed great popularity in the $90 \mathrm{~s}$, which is a better choice due to a more numerous target group of viewers interested in this genre.

Film adaptations of required readings (such as "Pan Tadeusz", "Zemsta", "W pustyni i w puszczy") are quite popular. In the case of such movies the total number of viewers is definitely higher due to mass interest of school youth watching them during school trips to the cinema organized by their teachers. However, the possibilities in this respect are limited by the number of books constituting required readings at school which have not yet been adapted and which can be adapted for movie storyline purposes in practice.

Another important element translating into high box office performance is good cast. It should definitely include the so-called "stars", that is well-known and popular actors mostly playing main characters. A popular cast works as a promotional element of the movie - the actors' faces and names should be properly highlighted in the advertising materials. Moreover, popular actors and actresses arouse more interest of the journalists, who have a context for possible interviews or for articles about given "stars". Writing scripts for certain actors or actresses, thanks to which the director is able to create a credible movie character, becomes a more and more frequent phenomenon. 
The production budget level determines box office performance to a limited extent. It is obviously a very important factor indispensable for a movie project becoming a reality. However, the amount of financial investment is not translated into a Polish film's success as regards audience turnout. There are high-budget productions that cannot attract viewers to the cinema, e.g. "Tajemnica Westerplatte" - its production cost PLN 13 million and the movie was seen by only 150 thousand viewers (Oświeciński), or medium- or low-budget films which enjoy great popularity due to interesting ideas and a well-narrated story (e.g. "Pod Mocnym Aniołem").

In the United States, where movie productions cost from tens to hundreds of millions of dollars, it is a common marketing practice to inform the public about these numbers. Such impressive amounts are meant to generate media hype around the movie and, combined with film-set documentaries, attract viewers to cinemas. Due to much more modest budgets, such endeavors are pointless in Poland. An average budget of a Polish movie is around PLN 4 million. Few productions are more expensive and the budgets of some of them are very low, staying at PLN 200 thousand. For comparison: "Spectre", the latest film about James Bond's adventures, will cost USD 300 million, which is PLN 150 million more than the Polish Film Institute (PISF) has spent to finance Polish movies for nine years of its operation (Wierzchowska, 2015).

\section{Distribution activities}

A box office success of a theatrical movie depends on appropriate planning activities to determine the number of movie copies and the movie release date.

The main problem that existed until recently was the cost of producing a sufficient number of movie copies. Due to the high costs of producing $35 \mathrm{~mm}$ copies, distributors limited their number to several dozens. This means that premiere shows were available only to such cinemas that were able to guarantee the highest revenues for distributors. Because of lower ticket revenues, local cinemas did not receive a movie until it had already gathered audience in big cities, which might happen only after a few months of its release.

From 2004 onwards cinemas were being digitized, which made the production of movies on a film tape unprofitable. Digital cinema means a replacement of "analogue" cinema projectors with digital ones that display movies not from a $35 \mathrm{~mm}$ tape, but from a hard drive or other type of electronic memory. Digital cinema brings a solution to problems with fast copy production and reaching the viewer. The costs are low, which increases the number of copies available on the market significantly, and their production time is much shorter in comparison with the $35 \mathrm{~mm}$ tape. Delivery of copies to cinemas is also simplified (satellite broadcast, streaming).

Digital technology brings much convenience to theatrical distribution (Morley, 1998, p. 6):

- no need to make hundreds of copies for demonstration and regular screening purposes, with no certainty whether predictions as to the numbers will be accurate

- no danger that the courier will not timely deliver the copy for the premiere show

- no concern that any of the copies may be stolen or "borrowed" to be later added to a purchased product in another part of the world with no consequences

- a guarantee of unchanging, high-quality copies identical to the film master copy

- $\quad$ no obligation to produce countless language versions on separate copies

- $\quad$ no need to release several different audio formats

- $\quad$ no problem of impurities on copies such as settling dust, scratches and scores

At present there are nearly 1,000 screening rooms equipped with modern digital projectors in Poland. All Polish multiplexes are fully digitized. Polish art-house and local cinemas which do not have money to purchase a projector themselves may apply for funding from the Polish Film Institute (Cyfryzacja w Polsce, 2015). 
When planning a movie release date, the demand seasonality on the motion picture market should be taken into account. In contrast to the United States, the most favorable period for a film premiere are the first months of each year: January, February and March. However, this does not always hold true. In early spring there is usually one weekend with an unexpected drop in attendance - a movie that unluckily happens to be screened then becomes a cinematic failure. For example, this was the case at the weekend of 16-19 March 2012, when "Hans Kloss. Stawka większa niż śmierć" and "Mirror Mirror" premiered. The sun shone more intensively, no one went to cinemas, which proved to be very important for the performance of both movies.

Early autumn is another favorable date to release a movie in Polish theatres due to the forthcoming Gdynia Film Festival held in September. This event builds and strengthens awareness of the movie. The work of accredited journalists is invaluable for distributors and audiences. If a movie has commercial potential and is also successful at Gdynia Festival, the first part of the campaign, i.e. building movie awareness, has been completed. This was the case of such motion pictures as: "Jesteś Bogiem" and "Chce się żyć". The premiere date of Paweł Pawlikowski's "Ida" was rescheduled from November to October, when the movie won the "Złote Lwy" (Golden Lions) First Prize. Awards and critical acclaim were highlighted in its promotional campaign.

In spring, summer and weeks before Christmas the audience is reduced and good performance of Hollywood shows can be expected then.

\section{Information activities}

In the United States a generally accepted market practice is to invite movie critics to special previews in order to provide them with the necessary film material to write a review. A significant contribution to the development of the theory concerning the role of opinion leaders on the movie market was made by J. Eliashberg and S.M. Shugan (1997). They identified two alternative functions that film critics can perform on the movie market. Film critics may be opinion leaders influencing purchasing decisions of cinema audiences, thus exerting a decisive influence on the sales of a given motion picture (i.e. "influencers"), or anticipators of viewers' behavior on the theatrical movie market, their attitudes towards the movie and the degree of their acceptance of the motion picture, foreseeing its possible success or failure without affecting sales (i.e. predictors) (Eliashberg and Shugan, 1997, pp. 68-79).

In Poland, in contrast to the US market, film critics' reviews neither affect cinema attendance directly nor play a persuasive role. This does not mean that previews organized in view of journalists writing film reviews made available to the public before the premiere should be given up. It is important to remember that each item of news about a movie appearing in the mass media has an informative function and builds awareness among the audience.

The ultimate market verification of a motion picture lies in the hands, or rather eyes, of the viewers, who share their opinions on the movie with other consumers. In analyzing the motion picture market on its demand side, A. De Vany and W.D. Walls (1996) proposed a behavioral model showing the behavior of cinema audiences that suggests a strong correlation between their opinions and the demand for a motion picture (De Vany and Walls, 1996, p. 1510). Viewers leave cinema with certain memories and impressions which they immediately share with other consumers (Eliashberg et al., 2000, p. 227).

The buzz marketing is a recognized form of communication on the movie market due to high credibility of the messages passed between the audience members. Polish viewers are more likely to believe the positive opinions of other viewers than the reviews of professional film critics. These conclusions are consistent with the study results of Ch. Dellarocas, F.A. Neveen and Z. Xiaoquan (2007) indicating that the assessment made by viewers is a variable more strongly correlated with the box office performance than with film critics' ratings (Dellarocas et al., 2007, pp. 39-41). J.A. Chevalier, D. Mayzlin (2006) stress that today's interpersonal communication 
is not limited to the traditional form of transmitting information personally, but can be carried out via the Internet (Chevalier and Mayzlin, 2006, pp. 345-346). The Internet is the most perfect medium for spreading viewers' opinions on a movie. The expansion of movie websites, where users are responsible for the content or may freely express their opinions and appraise it, makes the exchange of opinions and recommendations concerning movies very easy. Nevertheless, encouraging discussion on the Internet can have either a negative or positive effect on the success of a movie. Because reviews and opinions travel so fast, good word-of-mouth can replace expensive large-scale marketing efforts and yet achieve excellent results (Mangold and Faulds, 2009).

Furthermore, the model proves that the number of viewers in the first week of the run determines the final box office performance. The life cycle of a film in the cinematic channel is short; therefore, marketing activities should be conducted prior to the movie premiere in theatres. The cinema premiere is the beginning of a film's life, which may be compared with the launch of a new brand or a new product on the market. A promotional campaign, even if limited to a minimum, is necessary in such a situation to inform viewers that a new movie has appeared on the market.

The key element in the pre-premiere phase is to deliver the message about a movie production to the audience, with the aim of establishing the awareness of the upcoming movie, raising interest prior to the actual distribution to theatres and arousing curiosity and willingness to see the movie in its potential viewers.

Tools available to the distributor responsible for the movie promotion include, among others, paid advertising in the media, on external carriers and in the cinema. The second promotion element is PR, that is an activity resulting in journalistic notes, reviews, interviews, radio and television coverage. Attendance at festivals and awards were important elements of the promotion of Tomasz Wasilewski's "Płynące wieżowce". The director is not an artist widely known in Poland, hence the film distributor was concerned that the movie should appear at world film festivals first. The awards it won and its favorable reviews led to the positive rhetoric about "Płynące wieżowce".

The Internet is a relatively new place for campaigns. In addition to film websites such as Filmweb.pl or Stopklatka.pl, a movie needs to be mentioned on general websites, where it is much more difficult to get the message about a film across.

Virtual promotions rely on marketing activities using social media. Using social networking to its fullest extent in a marketing campaign allows producers to create a two-way discussion with potential viewers. Social media marketing cannot be a one-sided flow of information from a movie studio to a viewer that traditional marketing relied on in the past. Companies that are encouraging viewer participation in the social media campaign are revolutionizing the way movies are marketed (Elliott, 2011). By investing in a relationship with Internet users, a movie creates an audience who feel partial ownership of the movie and are therefore interested in its success.

There are many ways of using social media websites for promoting movies. Some examples of this include creating Twitter accounts for a movie, and tweeting updates, premieres, actor/ actress interviews, or give-away tie-ins. A marketing company might also make a Facebook page for a movie, encouraging people interested to "Like" their page and share it with their friends. YouTube can be used as a platform to not only show trailers, but also to create a channel dedicated to all official promos for a particular movie. By actively utilizing each channel of social media, a movie that would not normally garner a nationwide release might earn one. Though the trend in marketing through social media is a growing one, as of now it is difficult to determine the effectiveness of social media marketing. Many films are now attempting to use both traditional marketing and social media marketing, which makes it challenging to differentiate between them. 


\section{CONCLUSION}

The causal analysis carried out for the purposes of this article helped systematize the knowledge about factors determining box office performance in Poland. When planning and organizing marketing activities to efficiently manage theatrical movie sales, the specificity of the life cycle of a movie product in the cinematic channel should be taken into account: the prepremiere phase in the cinematic channel, premiere phase and post-premiere phase.

The pre-premiere phase is the period before film distribution in cinemas begins. The life cycle of a film in the cinematic channel is short; therefore, marketing activities should be conducted prior to the movie premiere in theatres. The key element in the pre-premiere phase is to deliver the message about the movie production to the audience, with the aim of establishing the awareness of the upcoming movie, raising interest prior to the actual distribution to theatres and arousing curiosity and willingness to see the movie in its potential viewers.

The premiere phase is the first week of a film's run, that is the first phase of the life cycle of a motion picture. The primary marketing aim is to generate the highest possible box office revenues and gain a significant market share in a given week. Since the first phase of sales is crucial for a movie's final success as regards audience turnout, the film producer's marketing activities should be targeted at both the demand side (cinema viewers) and the supply side (the distributor and cinema operators) of the market.

Persuasive promotional activities that encourage the purchase and distribution activities that ensure sufficiently broad availability of a movie in cinemas, i.e. an adequate number of shows per day, are vital.

The post-premiere phase is the second phase of a film's life cycle, comprising next weeks of its run until its final withdrawal from cinemas.

In the case of the post-premiere phase, the primary objective of producers' activities should be to minimize the decrease in weekly sales, which is a characteristic trend on the theatrical movie market. This objective is achieved if viewers have positive experiences of the film and share their opinions with other consumers. In this period, in contrast to the pre-premiere phase, factors reflecting the product quality such as: the script, genre and cast become more important as they affect the final box office performance in Poland.

Taking into account further research development in this area, some limitations of this analysis and directions for further research should be identified.

A key research limitation is the set of factors included in the model and their operationalization. While selecting the model variables, the main objective was to take into consideration as many factors that could potentially determine the sales of a film product as possible. It should be emphasized that film products are evaluated both in terms of their market value reflected in the box office performance and in terms of their artistic value ensuring appreciation by the film industry (Addis and Holbrook, 2008, p. 88). This analysis excluded the variable expressing the film industry appreciation manifesting itself as awards granted to individual films, their creators and actors in various categories.

Some US researchers analyzing the relationship between the appreciation of a movie's artistic quality and its box office performance took into account this variable (Holbrook, 1999; HennigThurau at al., 2007; Holbrook and Addis, 2008; Holbrook, 2005; Prag and Casavant, 1994; Litman, 1983; Sawhney and Eliashberg, 1996; Sochay, 1994). The most popular film award, which enjoys the highest international renown, is The Academy Award, commonly known as the Oscar, awarded by the US Academy of Motion Picture Arts and Sciences. Rarely is this factor taken into account by researchers analyzing the box office success, for two reasons. Firstly, film awards are mainly awarded to American movies, which renders the use of this variable impossible for an analysis 
of domestic productions on other foreign markets. Secondly, the Academy Awards ceremony is often held after theatrical premieres of many films, which does not allow for specifying explicit relationships between this factors and the number of viewers.

In Poland there are similar competition initiatives and the most popular and acclaimed ones include: Zbyszek Cybulski Award, Orzeł (Eagle) Award, Złote Lwy (Golden Lions) - the prize awarded at Gdynia Film Festival. However, film projects evaluated in these competitions are frequently productions whose life cycle has already been completed in the cinematic channel.

In the light of further development of the domestic film production, further research directions in analyzing the box office performance determinants should take into account a longer time horizon and a bigger research sample including new Polish motion pictures.

It should be highlighted that the sales regression function specified in this article illustrates certain regularities characteristic of the entire class of products. The analysis covered all motion pictures with no barriers to access to the necessary information. Given the vast diversity of film productions, this may be a research limitation since possible differences in the development of a different set of box office performance determinants for individual genres were disregarded. Taking into consideration the development of cinematic production in Poland, further research should include regression functions for homogeneous research samples. Referring to studies by M.S. Sawhney and J. Eliashberg (1996), a distinction should first be made between two specific types of worldwide cinematic production: commercial films addressed to broad, mass audience treating the cinema as a form of entertainment and art films that are ambitious, addressed to selective audience who treat the cinema as a cultural development element (Sawhney and Eliashberg, 1996).

The regression model presented in this article applies to sales determinants of Polish productions only. As shown by market data concerning the structure of motion pictures according to the country of production, the dominant group are foreign films (American and European). In order to obtain a complete picture of the specificity of box office performance determinants in Poland, separate regression models should be established for three research samples taking into account a division into Polish, American and European films.

Another complementary research direction should be an attempt to grasp a possible effect of the country of origin on the Polish motion picture market, that is to determine how information on the country where the film was produced affects cinema audiences' purchasing decisions.

Those financially involved in cinematic productions benefit from sales of a film product in various distribution channels. A research area which has not been scientifically explored so far, either on the Polish market or in the various European countries, is the identification of box office performance determinants in other movie distribution channels (DVD, "pay-per-view" system, television). The causal analysis conducted in this case should be based on regression models designed for each sequential distribution channel prevailing on the movie market (a set of variables and their operationalization adapted to the specificities of each channel).

An issue still to be solved is also the influence of sales in the first theatrical distribution channel on the interest in the film in other channels as well as the impact of the duration of a market gap in the movie availability on the market (in particular between the two key channels: cinema and DVD) from the perspective of maximizing revenues from film product sales.

As for foreign films that premiere on many world markets, the problem of creating independent sources of revenue from film product sales should also involve a definition of relationships between the number of viewers on the primary market and the audience turnout on subsequent 
foreign distribution markets, and the links between the total motion picture sales and the duration of a market gap in movie commercialization in other countries.

Finally, it is worth highlighting that the sales regression analysis presented should be verified by a quantitative panel study.

Due to its dynamic nature involving the collection of data from the same group of people (sample, panel) at several time points, a panel study would allow the identification of certain regularities concerning the stability and variability of cinema audience preferences. A comparison of the results of a panel study on cinema audiences with those of the movie sales regression analysis would show similarities and differences in significance of individual determinants, thus allowing for full understanding of box office success.

\section{References}

Ainslie, A., Dreye, X. and Zufryden, F. (2005) 'Modeling movie life cycles and market share', Marketing Science, 24 (3), pp. 508-517.

Albert, S. (1999) 'Movie stars and the distribution of financially successful films in the motion picture industry', Journal of Cultural Economics, 23 (4), pp. 325-329.

Bagella, M. and Becchetti, L. (1999) 'The determinants of motion picture box office performance: evidence from movies produced in Italy', Journal of Cultural Economics, 23 (4), pp. 237-256.

Baimbridge, M. (1997) 'Movie admissions and rental income: the case of James Bond', Applied Economics Letters, 4 (1), pp. 57-61.

Baker, W.W. and Faulkner, R.R. (1991) 'Role as resource in the Hollywood film industry', American Journal of Sociology, 97 (2), pp. 279-309.

Basuroy, S., Chatterjee, S. and Ravid, A. (2003) 'How critical are critical reviews? The box office effects of film critics, star power, and budgets', Journal of Marketing, 67 (4), pp. 103-117.

Basuroy, S., Desai, K.K. and Talukdar, D. (2005) 'An empirical investigation of signaling in the motion picture industry’, Journal of Marketing Research, 43 (2), pp. 287-295.

Canterbery, E.R. and Marvasti, A. (2001) 'The U.S. motion pictures industry: an empirical approach', Review of Industrial Organization, 19 (1), pp. 81-98.

Chang, B.H. and Ki, E.J. (2005) 'Devising a practical model for predicting theatrical movie success: focusing on the experience good property’, Journal of Media Economics, 18 (4), pp. 247-269.

Chevalier, J.A. and Mayzlin, D. (2006) 'The effect of word of mouth on sales: online book reviews', Journal of Marketing Research, 43 (3), pp. 345-354.

Collins, A., Hand, Ch. and Snell, M.C. (2002) 'What makes a blockbuster? Economic analysis of film success in the United Kingdom', Managerial and Decision Economics, 23 (6), pp. 343-354.

PISF, Cyfryzacja w Polsce. Retrieved 21.03.2015 from http://www.pisf.pl/rynek-filmowy/rynek-filmowy/ cyfryzacja-kin.

Dellarocas, Ch., Neveen, F.A. and Xiaoquan, Z. (2007) 'Exploring the value of online product reviews in forecasting sales: the case of motion pictures', Journal of Interactive Marketing, 21 (4), pp. 23-45.

Delmestri, G., Montanari, F. and Usai, A. (2005) 'Reputation and strength of ties in predicting commercial success and artistic merit of independents in the Italian feature film industry', Journal of Management Studies, 42 (5), pp. $975-1002$.

Desai, K.K. and Basuroy, S. (2005) 'Interactive influence of genre familiarity, star power, and critics reviews in the cultural goods industry: the case of motion pictures', Psychology \& Marketing, 22 (3), pp. 203-224.

De Vany, A.S. and Lee, C. (2001) 'Quality signals in information cascades and the dynamics of the distribution of motion picture box office revenues', Journal of Economic Dynamics \& Control, 25 (3/4), pp. 593-614.

De Vany, A.S. and Walls, W.D. (1999) 'Uncertainty in the movie industry: does star power reduce the terror of the box office?', Journal of Cultural Economics, 23 (4), pp. 285-318.

Dhar, T., Sun, G. and Weinberg, Ch.B. (2012) 'The long - term box office performance of sequel movies', Marketing Letters, 23 (1), pp. 13-29.

Duan, W., Gu, B. and Whinston, A.B. (2008) 'The dynamics of online word-of-mouth and product sales. An empirical investigation of the movie industry', Journal of Retailing, 84 (2), pp. 233-242.

Einav, L. (2002) 'Seasonality and competition in time: an empirical analysis of release date decisions in the U.S. motion picture industry'. Retrieved 12.02.2014 from http://www.stanford.edu/ leinav/Release_Dates.pdf.

Elberse, A. (2007) 'The power of stars: do star actors drive the success of movies?', Journal of Marketing, 71 (4), pp. $102-120$. 
Elberse, A. and Eliashberg, J. (2003) 'Demand and supply dynamics for sequentially released products in international markets: the case of motion pictures', Marketing Science, 22 (3), pp. 329-347.

Eliashberg, J. and Sawhney, M.S. (1994) 'Modeling goes to Hollywood: predicting individual differences in movie enjoyment', Management Science, 40 (9), pp. 1151-1173.

Eliashberg, J. Jonker, J.J., Sawhney, M.S. and Wierenga, B. (2000) 'Moviemod: an implementable decision-support system for prerelease market evaluation of motion pictures', Marketing Science, 19 (3), pp. 226-243.

Elliott, S. (22.06.2011) 'Building a buzz in social media ahead of traditional marketing', New York

Times. Retrieved 21.03.2015 from http://www.nytimes.com/2011/06/23/business/media/23adco.html?_r=0.

Elliott, C. and Simmons, R. (2008) 'Determinants of UK box office success: the impact of quality signals', Review of Industrial Organization, 33 (2), pp. 93-111.

Faulkner, R. and Anderson, A. (1987) 'Short-term projects and emergent careers: evidence from Hollywood', American Journal of Sociology, 92 (4), pp. 879-909.

Ginsburg, V. and Weyers, S. (1999) 'On the perceived quality of movies', Journal of Cultural Economics, 23 (4), pp. 269-283.

Hadida, A.L. (2009) 'Motion picture performance: a review and research agenda', International Journal of Management Review, 11 (3), pp. 297-335.

Hand, Ch. (2001) 'Increasing returns to information: further evidence from the UK film market', Applied Economics Letters, 8 (6), pp. 419-421.

Hennig-Thurau, T., Houston, M.B. and Heitjans, T. (2009) 'Conceptualizing and measuring the monetary value of brand extensions: the case of motion pictures', Journal of Marketing, 73 (6), pp. 167-183.

Hennig-Thurau, T., Houston, M.B. and Sridhar, S. (2006) 'Can good marketing carry a bad product? Evidence from the motion picture industry’, Marketing Letters, 17 (3), pp. 205-219.

Hennig-Thurau T., Houston M.B. and Walsh G. (2007) 'Determinants of motion picture box office and profitability: an interrelationship approach', Review of Managerial Science, 1 (1), pp. 65-92.

Hennig-Thurau, T., Walsh, G. and Wruck, O. (2001) 'An investigation into the factors determining the success of service innovations: the case of motion picture', Academy of Marketing Science Review, 2001 (6), pp. 1-23.

Hirschman, E.C. and Pieros Jr, A. (1985) 'Relationships among indicators of success in Broadway plays and motion pictures', Journal of Cultural Economics, 9 (1), pp. 35-63.

Hixson, T.K. (2006) 'Mission possible: targeting trailers to movie audiences', Journal of Targeting, Measurement and Analysis for Marketing, 14 (3), pp. 210-224.

Holbrook, M.B. (1999) 'Popular appeal versus expert judgments of motion pictures', The Journal of Consumer Research, 26 (2), pp. 144-155.

Holbrook, M.B. (2005) 'The role of ordinary evaluations in the market of popular culture: do consumers have "good taste"?', Marketing Letters, 16 (2), pp. 75-86.

Holbrook M.B. and Addis M. (2008) 'Art versus commerce in the movie industry: a two -path model of motionpicture success', Journal of Cultural Economics, 32 (2), pp. 87-107.

Jansen, Ch. (2005) 'The performance of German motion pictures, profits and subsidies: some empirical evidence', Journal of Cultural Economics, 29 (3), pp. 191-212.

Jedidi, K., Krider, R.E. and Weinberg, Ch.B. (1998) 'Clustering at the movies', Marketing Letters, 9 (4), pp. $393-405$.

Kamakura, W. A., Basuroy, S. and Boatwright, P. (2006) 'Is silence golden? An inquiry into the meaning of silence in professional product evaluations', Quantitative Marketing and Economics, 4 (2), pp. 119-141.

Kerrigan, F. (2010) Film marketing, Oxford: Elsevier.

Krider, R.E. and Weinberg, Ch. B. (1998) 'Competitive dynamics and the introduction of new products: the motion picture timing game’, Journal of Marketing Research, 35 (1), pp. 1-15.

Lampel, J. and Shamsie, J. (2000) 'Critical push: strategies for creating momentum in the motion picture industry', Journal of Management, 26 (2), pp. 233-257.

Lee, F.L.F. (2006) 'Cultural discount and cross-culture predictability: examining the box-office performance of America movies in Hong-Kong', Journal of Media Economics, 19 (4), pp. 259-278.

Lehmann, D.R. and Weinberg, Ch.B. (2000) 'Sales through sequential distribution channels: an application to movies and videos', Journal of Marketing, 64 (3), pp. 18-33.

Litman, B.R. (1983) 'Predicting success of theatrical movies: an empirical study', Journal of Popular Culture, 16 (1), pp. $159-175$.

Litman, B.R. and Kohl, L.S. (1998) 'Predicting financial success of motion pictures: the 80's experience', Journal of Media Economics, 2 (2), pp. 35-50.

Liu, Y. (2006) 'Word of mouth for movies: its dynamics and impact on box office revenue', Journal of Marketing, 70 (3), pp. 74-89.

Mangold, W.G. and Faulds, D.J. (2009) 'Social media: the new hybrid element of the promotion mix', Business Horizons, 2009 (52), pp. 357-365.

Miller, D. and Shamsie, J. (2001) 'Learning across the life cycle: experimentation and performance among the Hollywood studio heads', Strategic Management Journal, 22 (8), pp. 725-738. 
Morley, S.A. (1998) 'Making digital cinema actually happen - what it takes and who's going to do it', Society of Motion Picture \& Television Engineers, conference proceedings, 1998 (7), pp. 1-16.

Moul, C. (2004) 'Word-of-mouth versus market saturation: explaining demand dynamics for movies and music', working paper, Department of Economics, Washington University.

Moul, C. (2007) 'Measuring word of mouth's impact on theatrical movie admissions', Journal of Economics \& Management Strategy, 16 (4), pp. 859-892.

Nelson, R.A., Donihue, M.R., Waldman, D.M. and Wheaton, C. (2001) 'What's an Oscar worth?', Economic Inquiry, 39 (1), pp. 729-754.

Oświeciński, R., 'Hity i kity, czyli gdzie są pieniądze?', film.org.pl. Retrieved 21.03.2015 from http://film.org.pl/kmf/ blog/hity-i-kity-czyli-gdzie-sa-pieniadze-27384/.

Prag, J. and Casavant, J. (1994) 'An empirical study of the determinants of revenues and marketing expenditures in the motion picture industry', Journal of Cultural Economics, 18 (3), pp. 217-235.

Ravid, S.A. (1999) 'Information blockbusters and stars: a study of the film industry', Journal of Business, 72 (4), pp. 463-492.

Reinstein, D.A. and Snyder, Ch.M. (2005) 'The influence of expert reviews on consumer demand for experience goods: a case study of movie critics', Journal of Industrial Economics, 53 (1), pp. 27-51.

Sawhney, M.S. and Eliashberg, J. (1996) 'A parsimonious model of forecasting gross box-office revenues of motion pictures’, Marketing Science, 15 (2), pp. 113-131.

Scott, A.J. (2004) 'Hollywood and the world: the geography of motion picture distribution and marketing', Review of International Political Economy, 11 (1), pp. 33-61.

Sedgwick, J. and Pokorny, M. (1999) 'Movie stars and the distribution of financially successful films in the motion picture industry’, Journal of Cultural Economics, 23 (4), pp. 319-323.

Simonoff, J.S. and Sparrow, I.R. (2000) 'Predicting movie grosses: winners and losers, blockbusters and sleepers', Chance, 13 (3), pp. 15-24.

Simonton, D.K., (2005a) 'Cinematic creativity and production budgets: does money make the movie?', Journal of Creative Behavior, 39 (1), pp. 1-15.

Simonton, D.K. (2005b) 'Film as art versus film as business: differential correlates of screenplay characteristics', Empirical Studies of the Arts, 23 (2), pp. 93-117.

Simonton, D.K. (2009) 'Cinematic success criteria and their predictors: the art and business of the film industry', Psychology \& Marketing, 26 (5), pp. 400-420.

Smith, S.P. and Smith, V.K. (1986) 'Successful movies: a preliminary analysis', Applied Economics, 18 (5), pp. 501-507.

Sochay, S. (1994) 'Predicting the performance of motion pictures', Journal of Media Economics, 7 (4), pp. 1-20.

Sood, S. and Dreze, X. (2006) 'Brand extensions of experiential goods: movie sequel evaluations', Journal of Consumer Research, 33 (3), pp. 352-360.

Svejenova, S. (2005) 'The path with the heart: creating the authentic career', Journal of Management Studies, 42 (5), pp. 947-974.

Wallace, W., Seigerman, A. and Holbrook, M. (1993) 'The role of actors and actress in the success of films: how much is a movie star worth?', Journal of Cultural Economics, 17 (1), pp. 1-27.

Walls, W.D. (1997) Increasing returns to information: evidence from the Hong Kong movie market, Applied Economics Letters, 4 (5), pp. 287-290.

Walls, W.D. (2005a) 'Demand stochastic, supply adaptation, and the distribution of film earnings', Applied Economics Letters, 12 (10), pp. 619-623.

Walls, W.D. (2005b) 'Modeling heavy tails and skewness in film returns', Applied Financial Economics, 15 (17), pp. 1181-1188.

Wierzchowska, M. (13.01.2015) Polskie filmy na kroplówce, Puls Biznesu. Retrieved 21.03.2015 from http://www. pb.pl/3982731,2178,polskie-filmy-na-kroplowce.

Wyatt, R.O. and Badgar, D.P. (1990) 'Effects of information and evaluation in film criticism', Journalism Quarterly, 67 (2), pp. 359-368.

Zuckerman, E. and Kim, T. (2003) 'The critical trade-off: Identity assignment and box office success in the feature film industry', Industrial and Corporate Change, 12 (1), pp. 27-67.

Zufryden, F.S. (1996) 'Linking advertising to box-office performance of new film release - a marketing planning model', Journal of Advertising Research, 36 (4), pp. 29-41.

Zufryden, F.S. (2000) 'New film website promotion and box-office performance', Journal of Advertising Research, $40(1 / 2)$, pp. 55-64. 